\title{
Topical Menthol Cream
}

National Cancer Institute

\section{Source}

National Cancer Institute. Topical Menthol Cream. NCI Thesaurus. Code C106431.

A topical cream containing menthol that both causes a localized cooling sensation and has analgesic activities. Upon topical application, menthol acts on the cold-sensitive transient receptor potential cation channel subfamily M member 8 (TMPR8), which provides a cooling sensation. This treatment also provides an analgesic effect through the activation of the inhibitory Group II/III metabotropic glutamate receptors (mGluRs). This may decrease neuropathic pain from chemotherapy. In addition, the topical application of menthol causes vasodilation. 